\title{
Pelatihan Tenaga Pendidikan di Sekolah Esa Sejahtera Pekanbaru: Sebuah Pendekatan Kualitatif
}

\author{
Rudi Fahrudi ${ }^{1}$, Anita Maharani ${ }^{2}$, Achmad Fauzi ${ }^{3}$ \\ ${ }^{1}$ Program Pasca Sarjana, Universitas Terbuka, ${ }^{2}$ Program Magister, Universitas Bina Nusantara \\ ${ }^{3}$ Program Sarjana, Universitlas Bhayangkara \\ Email korespondensi: anita.maharani@binus.edu
}

\begin{abstract}
The purpose of this study is to describe the application of education personnel training in a private school located in Pekanbaru. Conceptually, the literature referred to includes an explanation of training, training approaches and implementation. The research method referred to in this research is to use a qualitative approach, and specifically to raise a case study in one school. The results obtained were that the training was carried out through discussions with various parties, referring to the curriculum and making it in the syllabus, and the training approach was considered based on conditions in school.
\end{abstract}

Keywords: Training, Personnel, Education, Qualitative

Abstrak. Tujuan penelitian ini adalah menggambarkan penerapan pelatihan tenaga Pendidikan di sebuah sekolah swasta yang berlokasi di Pekanbaru. Secara konseptual, literatur yang diacu antara lain penjelasan tentang pelatihan, pendekatan dan implementasi pelatihan. Metode penelitian yang diacu dalam penelitian ini adalah menggunakan pendekatan kualitatif, dan spesifik mengangkat studi kasus di satu sekolah. Hasil yang diperoleh adalah pertimbangan pelatihan dilakukan melalui diskusi dengan beragam pihak, mengacu pada kurikulum dan membuatnya dalam silabus, serta pendekatan pelatihan dipertimbangkan berdasarkan kondisi di sekolah.

Kata Kunci: Pelatihan, Tenaga, Pendidikan, Kualitatif

\section{PENDAHULUAN}

Bahwa setiap permasalahan mutu pendidikan di Indonesia yang dinilai rendah maka permasalahan tersebut langsung diarahkan kepada tenaga pendidik yang dinilai tidak mempunyai kualitas kompetensi yang mumpuni, padahal masalah kualitas kompetensi tenaga pendidik tidak bisa menjadi tanggung jawab daripada tenaga pendidik saja, hal ini merupakan permasalahan nasional yang menjadi tanggung jawab para pemangku kebijakan, dimana dalam hal ini pemerintah untuk sekolahsekolah negeri ataupun yayasan/manajemen sekolah swasta untuk sekolah-sekolah swasta. Tentunya tenaga pendidik tidaklah sendirian dalam upaya meningkatkan kompetensi yang dimiliki diperlukan suatu usaha yang terorganisir dan sistematik dalam menyikapi permasalahan kualitas kompetensi tenaga pendidik.
Karena kualitas kompetensi tenaga pendidik sangat berdampak langsung terhadap hasil proses belajar mengajar kepada peserta didik maka diperlukan suatu upaya peningkatan kualitas kompetensi yang dimili tenaga pendidik, upaya tenaga pendidik dalam peningkatan kualitas kompetensinya akan memiliki kesiapan mengimplementasikan kompetensi sebagaimana diatur dalam PP No. 74 Tahun 2008, yakni yang berkaitan dengan kompetensi pedagogik, kompetensi kepribadian, kompetensi sosial dan kompetensi profesional, serta kompetensi tambahan yang juga mempunyai dampak terhadap kualitas proses belajar mengajar yaitu 1) kompetensi pembelajaran aktif, 2) kompetensi pengelolaan kelas dan 3) kompetensi berbahasa Inggris.

Upaya untuk peningkatan pengetahuan dan ketrampilan mengenai kompetensi tenaga pendidik adalah dengan dilakukannya pelatihan. Pelatihan adalah suatu proses yang dilalui oleh 
orang, dalam rangka memperoleh kemampuan tertentu, yang memiliki tujuan akhir membantu tercapai tujuan organisasi. Secara terbatas, pelatihan menyediakan para karyawan dengan pengetahuan yang spesifik dan dapat diketahui serta ketrampilan yang digunakan dalam pekerjaan saat ini (Mathis \& Jackson, 2002). Ditambahakan oleh Mathis dan Jackson (2002) bahwa bekerja, adalah proses "memahami" yang berkelanjutan, dan hal ini menjadi keutamaan dari seluruh aktivitas pelatihan. Kemampuan untuk belajar harus disertai dengan motivasi atau keinginan untuk belajar.

Sekolah Esa Sejahtera (SES) Pekanbaru sebuah sekolah bertaraf nasional plus yang bernaung di bawah manajemen MAS Group (Authorized Automotive Dealer - Ford, Suzuki, Subaru, Mercedez Bens, Vespa Piaggio \& Rent A Car), yang merupakan sekolah swasta di Pekanbaru dengan jenjang pendidikan TK, SD dan SMP, dengan berbadan hukum Yayasan Esa Sejahtera. Adapun Visi dari SES adalah "menjadi sekolah terkemuka dengan pelayanan prima untuk menciptakan komunitas belajar yang siap menghadapi tantangan dan meraih kesempatan melalui pendekatan kreatif". Misi dari SES adalah "melaksanakan proses pendidikan dengan program dan fasilitas berkualitas didukung oleh sumberdaya manusia yang kompeten sehingga terlaksananya pendidikan yang dinamis dan berkesinambungan".

Dalam operasionalnya Sekolah Esa Sejahtera dijalankan berdasarkan visi dan misi sebagaimana tersebut di atas, yaitu melaksanakan tujuan pendidikan nasional yang didasarkan pada peraturan perundang-undangan yang berlaku dan sebagai sekolah swasta sebagai wadah bisnis yang membiayai sendiri operasionalnya, sehingga SES mempunyai orientasi memberikan pelayanan prima kepada pelanggan (peserta didik dan orang tua) sehingga menjadi sekolah pilihan di Pekanbaru, dengan menjadi sekolah pilihan tentunya SES akan mempunyai revenue yang teratur berdasarkan target yang ditetapkan. Setiap saat SES selalu berupaya untuk meningkatkan kulitas pelayanan kepada pelanggan baik dari penyiapan sarana dan prasarana yang berkualitas dalam proses belajar.
Pendapat mengenai kompetensi tenaga pendidik yang disampaikan Fathivajargah dalam Ilandou \& Zand (2011), guru yang pantas dipekerjakan adalah yang memiliki kompetensi kognitif (kesadaran diri, kesadaran pembelajar, dan kesadaran atas proses belajar mengajar), emosional (berdasarkan minat, nilai, dan sikap), dan praktikal (berkaitan dengan murid, kelas, sekolah, dan masyarakat). Semakin meningkatnya upaya untuk memperbaiki kualitas pendidikan mendorong penelitian mengenai kompetensi guru terus bertambah. Oleh karena itu daftar kompetensi guru senantiasa diperbarui sejalan dengan perubahan dan tantangan yang dihadapi guru dalam konteks dampak kebijakan pendidikan global (Kovač, Eafajac \& Buchberger, 2014). Sependapat dengan pernyataan tersebut dimana SES juga berupaya meningkatkan kualitas penyampaian materi kepada peserta didik melalui tenaga pendidik yang mempunyai kompetensi mumpuni. Sebuah institusi sekolah sebagaimana layaknya perusahaan dalam rangka mencapai tujuan pendidikan tentunya memerlukan manajemen. Terry dalam Latief dan Latief (2018) menyatakan "management is distinct process consisting of planning, organizing, actuating, and controlling; Utilizing both science and arti and followed in order to accomplish ore-determined objectives".

\section{Konsep manajemen pendidikan} sebagaimana pendapat Hamalik (2015) bahwa, manajemen pendidikan sebagai suatu proses atau sistem pengelolaan kegiatan pengelolaan pada suatu sistem pendidikan bertujuan untuk keterlaksanaan proses belajar mengajar yang baik mencakup : (a) program kurikulum yang meliputi administrasi kurikulum, metode penyampaian, sistem evaluasi, sistem bimbingan; (b) program ketenagaan; (c) program pengadaan dan pemeliharaan fasilitas dan alat-alat pendidikan; (d) program pembiayaan; (e) program hubungan masyarakat.

Pelatihan diartikan oleh Ivancevich dkk (2008) sebagai suatu usaha untuk meningkatkan kinerja pegawai dalam pekerjaannya, sekarang atau dalam pekerjaan lain yang akan dijabatnya, bahwa pelatihan merupakan sebuah proses sistematis untuk mengubah perilaku kerja seorang/kelompok pegawai dalam usaha 
meningkatkan kinerja organisasi. Desler (2009) menambahkan bahwa pelatihan adalah proses mengajarkan karyawan baru atau yang ada sekarang, ketrampilan dasar yang mereka butuhkan untuk menjalankan pekerjaan mereka. Pelatihan adalah serangkain usaha untuk meningkatkan mutu Sumber Daya Manusia dalam dunia kerja.

Proses perancangan pendidikan (training design process) mengacu pada pendekatan sistematis untuk mengembangkan programprogram pelatihan. Perancangan sistem pengajaran (instructional design system- IDS) dan model perancangan, pengembangan, pelaksanaan, dan evaluasi (analysis, design, development, implementation, evaluation ADDIE) merupakan dua jenis proses perancangan pelatihan tertentu yang mungkin anda ketahui (Noe, dkk : 2010). Pelatihan dirancang untuk membantu orgaisasi-organisasi mencapai tujuan-tujuannya. Menentukan kebutuhan pelatihan organisasai memerlukan tahap diagnostik dan menyusun tujuan-tujuan pelatihan (Mathis \& Jackson, 2002).

Model Evaluasi program pelatihan yang sering digunakan adalah model Kirkpatrick, dimana pada model Kirkpatrick merupakan model evaluasi pelatihan yang terdiri dari empat level. Model teori tersebut diketahui sebagai Teknik Empat Tingkatm untuk melakukan evaluasi program pelatihan. Secara prinsip, teori ini menerangkan bahwa proses evaluasi suatu pelatihan terdiri dari empat tahapan/level yaitu level 1 digunakan untuk mengukur reaction, level 2 digunakan untuk learning, level 3 digunakan untuk mengukur behavior, dan level 4 digunakan untuk mengukur result.

\section{METODE}

Bogdan \& Taylor (dalam Gunawan 2017) menyebutkan, penelitian kualitatif adalah prosedur penelitian yang menghasilkan data deskriptif berupa kata-kata tertulis atau lisan dari orang-orang dan perilaku yang dapat diamati yang diarahkan pada latar dan individu secara holistik (utuh). Pendekatan yang digunakan dalam penelitian ini adalah pendekatan analisis kualitatif. Penelitian studi kasus adalah penelitian yang meneliti fenomena kontemporer secara utuh dan menyeluruh pada kondisi yang sebenarnya, dengan menggunakan berbagai sumber data, menggunakan sumber data, sebagai upaya untuk mencapai validitas dan reliabilitas (Gunawan, 2017). Informan penelitian ini ada empat, yakni manager sekolar, kepala akademis dan riset pengembangan, kepala sekolah, dan tenaga pendidik. Pedoman wawancara terlampir di akhir bagian naskah ini dan prosedur pengumpulan data melalui wawancara dan menggunakan Teknik snowball sampling. Metode analisis data dilakukan berdasarkan pendekatan yang pernah diungkapkan oleh Miles dan Huberman (dalam Sugiyono, 2017), yakni ada tiga tahapan yang dilakukan pertama melakukan reduksi terhadap data, memaparkan data yang ditemukan, dan kemudian menarik kesimpulan serta verifikasi. Penelitian kualitatif menarik untuk dilakukan dan di sisi lain rentan terhadap keabsahan, dengan demikian peneliti mengacu pada empat kriteria uji keabsahan data, antara lainnya adalah kredibilitas, mampu untuk ditransfer, kebergantungan, dan kepastian.

\section{HASIL DAN PEMBAHASAN}

Sekilas mengenai profil Sekolah Esa Sejahtera atau SES Pekanbaru. Sekolah Esa Sejahtera (SES) Pekanbaru merupakan sekolah swasta yang merupakan bagian daripada MAS Group (Vehicle Authorized Dealer - Ford, Subaru, Suzuki, Mercedes Benz, Vespa Piaggio \& Rent a Car). Adapun secara operasional Sekolah SES merupakan sebuah sekolah swasta national-plus umum yang meliputi pendidikan anak usia dini (Kelompok Bermain, TK), SD dan SMP, dalam proses belajar mengajar menggunakan bahasa pengantar bahasa Indonesia dan untuk subjek pelajaran tertentu menggunakan bahasa Inggris (bahasa Inggris, matematika, sains) serta bahasa Mandarin untuk subjek pelajaran bahasa Mandarin. Sebagai sekolah swasta yang membiyai sendiri maka SES mempunyai tanggung jawab sebagai strategyc business unit (SBU) yang secara operasional berorientasi pada revenue. Dalam memberikan pelayanan kepada peserta didik mengutamakan perhatian sampai pada hal-hal kecil yang berhubungan dengan perkembangan pendidikan dan kebahagian anak.

Tahapan pelatihan yang berdasarkan kaidah manajemen adalah sebagai berikut: 1) need assessment yang didasarkan oleh organisasi, individu dan tugas, 2) pemilihan 
instruktur atau trainer, 3) pelaksanaan training berdasarkan need assessment, 4) peralihan training, 5) penggunaan keterampilan hasil training terhadap keahlian, pengetahuan dan sikap, 6) metode pelatihan yang digunakan (misalnya presentasi instruktur, pengalaman praktik, pemodelan perilaku, penggunakan video, dan e-learning), 7) metode evaluasi training berdasarkan model Kirkpatrick.

Penerapan pelatihan dilakukan berdasarkan matriks pelatihan yang terdiri dari: 1) modul pelatihan, 2) agenda pelatihan, 3) workshop yang dilakukan manajemen sekolah untuk kompetensi pelayanan prima.

Setelah itu manajemen kurikulum untuk pelatihan di sekolah yang dijadikan obyek penelitian ini mengacu pada keperluan sekolah yang kemudian dituangkan dalam bentuk silabus pelatihan. Kemudian, terkait dengan kompetensi tenaga pendidik, antara lainnya 1) manajemen kelas, 2) pembelajaran aktif, 3) Bahasa Inggris, 4) pedagogic, 5) professional, 6) social, 7) kepribadian. Sistem penilaian kinerja yang dilakukan di SES terhadap tenaga pendidik adalah berikut: a) Faktor-faktor yang dinilai adalah (1) pencapaian tenaga pendidik terhadap kompetensi Active learning, Classroom management, Kemampuan bahasa Inggris, Pedagogik, Profesional; (2) pencapaian tenaga pendidik dalam administrasi pengajaran berupa penyusunan Rencana Kerja Sekolah (RKS), Rencana Pelaksanaan Pembelajaran (RPP) yang disusun dari silabus untuk pencapaian kompetensi dasar, pembuatan soal-soal dan administrasi evaluasi terhadap peserta didik; (3) kehadiran tenaga pendidik di tempat kerja (daftar kehadiran, daftar pencapiaan beban mengajar, keterlambatan di tempat kerja), b) proses pelaksanaan penilaian kinerja adalah : (1) penilaian kinerja didasarkan penugasan dan beban jam pengajaran kepada tenaga pendidik; (2) Kepala Sekolah melakukan penilaian kompetensi berdasarkan observasi kelas dan stimulant lainnya, penilaian penyusunan RKS, RPP, hasil pembuatan soal-soal, hasil dalam melakukan evaluasi kepada tenaga pendidik, kehadiran ditempat kerja (keterlambatan), pencapaian terhadap beban jam pengajaran; (3) Kepala Sekolah dalam melakukan penilaian kepada tenaga pendidik berdasarkan skala yang terdapat kamus kompetensi yang telah ditetapkan manajemen, hal ini dimaksudkan dalam melakukan penilaian berdasarkan standarisasi; (4) Kepala Sekolah memberikan rekap data hasil penilaian tenaga pendidik kepada Kepala Akademis untuk dilakukan analisa terhadap pencapain kinerja tenaga pendidik, berdasarkan hasil analisa tersebut jika terdapat area kelamahan maka Kepala Sekolah dan Kepala Akademis melakukan konseling kepada tenaga pendidik mengenai perbaikan area kelamahan tersebut, serta meminta masukan terhadap kendala-kendala yang dihadapi tenaga pendidik dalam mencapai target yang telah ditentukan. (5) Rekap hasil penilaian tenaga pendidik yang telah dianalisa dan hasil konseling terhadap area kelemahan oleh Kepala Akademis dilaporkan kepada Manager, kemudian berdasarkan laporan tersebut Manager melakukan analisa terhadap proses penilaian kerja, instrument penilaian kinerja, dan aspek-aspek penilaian kerja, hasil penilaian kinerja dan hasil konseling area kelemahan. Selanjutnya Manager melakuan diskusi dengan Kepala Akademis dan Kepala Sekolah untuk menindak lanjuti hasil penilaian kinerja tersebut, jika penilaian kinerja ada pada skala "Baik Sekali" dan "Baik" maka kepada tenaga pendidik tersebut akan diberikan reward, jika penilaian kinerja ada pada skala "Cukup" dan "Buruk/Kurang" maka kepada tenaga pendidik tersebut dilakukan evaluasi kembali apakah dapat dilakukan peningkatan area kelemahan dengan dilakukan pelatihan atau jika hasil penilaian kinerja mempunyai indikasi tenaga pendidik tersebut tidak cukup mampu menjadi tenaga pendidik sesuai spesifikasi SES maka akan dilakukan pemutusan hubungan kerja.

\section{KESIMPULAN}

Penelitian ini merupakan pengkajian tentang penerapan pelatihan tenaga pendidik pada manajemen SES Pekanbaru sebagai uapaya untuk peningkatan kompetensi sumber daya manusia secara keseluruhan dan secara khusus kepada tenaga pendidik, dengan kompetensi tenaga pendidik yang miliki setelah pelatihan maka tenaga pendidik diharapkan mampu melaksanakan tugas-tugas yang berikan sesuai standar yang ditentukan, dimana secara 
simultan akan berpengaruh terhadap kinerja institusi.

Keberhasilan penerapan pelatihan ditentukan daripada berfungsinya sistem manajemen pendidikan pada manajemen SES secara baik, yang dimaksud sistem berjalan dengan adalah suatu sistem yang didasarkan pada pola pikir manajemen. Sebagai bagian daru suatu sistem utama maka sistem manajemen pelatihan tidak dapat berdiri sendiri, diperlukan sistem-sistem lain baik itu manajemen SDM sebagai umbrella system pengelolaan SDM dimana sistem manajemen pelatihan merupakan bagian dari sistem tersebut, juga sistem pendamping seperti sistem manajemen kurikulum, sistem manajemen kinerja.

Berdasarkan penelurusan dan penggalian data yang didapat peneliti melalui informan kunci dan informan, dalam hal ini peneliti selain daripada pelurusan dan penggalian data primer dan sekunder terhadap kompetensi-kompetensi tenaga pendidik yang diterapkan sebagai spesifikasi tenaga pendidik di SES yaitu kompetensi active learning, classroom management, bahasa Inggris, pedagogik, sosial, kepribadian dan professional, juga dilakukan penelurusan dan penggalian terhadap sistem manajemen yang terdapat pada manajemen SES yang dimaksudkan agar sistem manajemen pelatihan dapat berjalan dengan baik.

Hasil temuan penelitian dapat diberikan kesimpulan bahwa terdapat kompetensi tenaga pendidik yang memerlukan peningkatan yang sesuai dengan standar kompetensi yang ditetapkan, peningkatan kompetensi tersebut adalah melalui perencanaan dan implementasi pelatihan yang komprehensif dan sesuai dengan pola pikir manajemen.

\section{SARAN}

Berdasarkan

daripada hasil penelitian sebagaimana pemaparan tersebut di atas, dengan peneliti mencoba untuk menyampaikan saran sebagai berikut :

1. Pelatihan terhadap peningkatan kompetensi tenaga pendidik tidak hanya terbatas dari kompetensi active learning, classroom management, pedagogik tetapi terhadap seluruh kompetensi-kompetensi tenaga pendidik yang ditetapkan oleh manajemen.

2. Pelatihan kompetensi sesuai PP No. 74/2008 sebaiknya manajemen SES mengandeng Dinas Pendidikan Kota Pekanbaru untuk mendapatkan pendampingan dalam keluasan dan kedalaman pemahaman mengenai kompetensi pedagogik, sosial, kepribadian dan professional. Serta meminta kepada Dinas Pendidikan Kota Pekanbaru tenaga pelatih/instruktur/fasilitator sebagai penerapan Training of Trainer kepada SDM yang mempunyai potensi untuk menjadi trainer.

3. Perancangan ulang, revisi ataupun perombakan sistem manajemen pendidikan, sistem manajemen SDM, sistem manajemen pelatihan, sistem manajemen kurikul, sistem manajemen penilaian kinerja yang sesuai dengan pola pikir manajemen

\section{DAFTAR PUSTAKA}

Gunawan, I. (2017). Metode Penelitian Kualitatif Teori \& Praktik Cetakan V. Jakarta : PT Bumi Aksara

Hamalik, O. (2017). Manajemen Pengembangan Kurikulum Cetakan ketujuh. Bandung : PT Remaja Rosdakarya

Hamalik, Oemar. (2015). Kurikulum dan Pembelajaran. Jakarta: Bumi Aksara

Ilanlou, M., \& Zand, M. (2011). "Professional Competencies of Teachers and the Qualitative Evaluation." ProcediaSocial and Behavioral Sciences, 29, 1143- $1150 . \quad \mathrm{https} / / /$ doi. org/10.1016/j.sbspro.2011.11.348

Ivancevich, John, M, dkk. 2008. Perilaku dan Manajemen Organisasi, jilid 1 dan 2 Jakrta : Erlangga.

Kovač, V., Rafajac, B., \& Buchberger, I. (2014). "Croatian Teacher Competencies Related to the Creation and Implementation of Education Policy." C.E.P.S Journal, 4(4), 51-73.

Latief, M. \& Latief, S. (2018) Teori Manajemen Pendidikan Edisi Pertama. Jakarta : PT PrenadaMedia

Mathis, R.L. and Jackson, J.H. (2002). Manajemen Sumber Daya Manusia 
Edisi Pertama. Jakarta : Salemba Empat

Noe, R.A., Hollenbeck J.R., Gerhart, B., and Wright P.M. (2010). Manajemen Sumber Daya Manusia : Mencapai Keunggulan Bersaing. Jakarta : Salemba Empat

Sugiyono (2017). Metode Penelitian Kualitatif Edisi ke 3, Bandung : Alfabeta 